\title{
O ESCRITOR, DENTRO/FORA: NOTAS ACERCA DA AUTORIA NAS NARRATIVAS DE BERNARDO CARVALHO E JULIÁN FUKS
}

\section{THE WRITER, INSIDE/OUTSIDE: NOTES ON AUTHORSHIP IN BERNARDO CARVALHO AND JULIÁN FUKS' NARRATIVES}

\author{
Shirley de Souza Gomes Carreira \\ Universidade do Estado do Rio de Janeiro, UFRJ, Rio de Janeiro, RJ, Brasil \\ Paulo César Silva de Oliveira \\ Universidade do Estado do Rio de Janeiro, UFRJ, Rio de Janeiro, RJ, Brasil
}

\begin{abstract}
Resumo: Este artigo versa sobre a questáo da imagem do autor a partir da análise crítica dos romances Simpatia pelo demônio, de Bernardo Carvalho, e A resistência, de Julián Fuks. Inicialmente, investigaremos o problema do autor em algumas referências teóricas essenciais à discussão da autoria, seja recuperando alguns pressupostos mais clássicos dos Estudos Literários, seja atualizando a reflexão em torno do nome e das práticas sócio-discursivas que legitimam os autores. Bernardo Carvalho e Julián Fuks instigam-nos a pensar as questóes de tempo, de espaço e de memória com base naquilo que Josefina Ludmer (2014) chama de crítica polifônica, isto é, o pensamento que introduz, na história do discurso crítico, uma multiplicidade de operações simultâneas demandadas pelos textos. A questão, como se verá nas obras de Carvalho e Fuks, será discutida por meio dessa polifonia crítica, com ênfase na legitimação e na patrimonialização do autor no campo intelectual, temas que não dizem respeito somente ao papel do escritor no sistema literário, mas também a uma intensa problematização ficcional que seus textos operam.
\end{abstract}

Palavras-chave: Autor; campo intelectual; práticas sociais.

Abstract: This article deals with the image of the author from the critical analysis of the novels Simpatia pelo demônio, by Bernardo Carvalho, and $A$ resistência, by Julián Fuks. Initially, we will investigate the author's question in some theoretical references essential to the problematization of authorship, either by recovering some classic questions from Literary Studies or by updating the problems of the name and the socio-discursive practices that legitimize the authors. Bernardo Carvalho and Julián Fuks provoke us to think about the issues of time, space and memory from what Josefina Ludmer (2014) calls polyphonic criticism, that is, the thought that introduces in the history of the critical discourse a multiplicity of simultaneous operations demanded by texts. The author's question, as will be seen in the works of Carvalho and Fuks, will be discussed through this critical polyphony, with emphasis on the legitimation and patrimonialization of the author in the intellectual field, a theme that not only concerns the role of the author in the literary system, but also requires an intense fictional problematization that his texts operate.

Keywords: Author; intellectual field; social practices. 


\section{Introdução}

Em Le bruisement de la langue (1984, p. 62), no capítulo dedicado à morte do autor, Roland Barthes afirmava que "bien que l' empire de l'Auteur soit encore três puissant (la nouvelle critique n'a fait bien solvente que le consolider), il va de soi que certains écrivains ont depuis longtemps dèjá tenté de l'ebranler". ${ }^{1}$ A história desse abalo na França, prossegue Barthes, pode ser rastreada já na tentativa de Stéphane Mallarmé de suprimir a figura do autor em favor da escrita como um novo paradigma da compreensão da obra. Para o teórico francês, Marcel Proust seria o escritor europeu que melhor amalgamaria e, por outro lado, confundiria a diferenciação entre autor e personagem, ao fazer, da vida de quem escreve, a própria obra e a obra, uma confissão de vida (BARTHES, 1984). As reflexões de Barthes se estenderam para fora do círculo europeu e ganharam matizes nas diversas recepçóes críticas nas literaturas do Ocidente; diante disso, as relaçôes múltiplas do texto com o mundo da vida vêm demandando constantes reflexóes e redefiniçôes, formando, assim, a matéria prima da reflexão teórica.

Não sem razão, Josefina Ludmer (2014) aponta que, uma vez inscrito em uma teoria, o texto deixa escapar alguns "restos" que desafiam a impenetrabilidade de qualquer modelo crítico, revelando múltiplas potencialidades - que transbordam das leituras -, obrigando o discurso crítico a declarar seus impasses e a confessar seus limites. Ludmer caracteriza a crítica como uma tentativa impossível, porém, necessária, de recolher a totalidade do que se desperdiça nas análises e nas aplicaçôes metodológicas. A questão do autor não escapa a esse imperativo: Michel Foucault (2001, p. 264) dizia haver uma "impossibilidade de tratá-lo [o autor] como uma descrição definida" ou "como um nome próprio comum", e Roland Barthes afirmava, em outro momento, que o autor se comporta como escrevente quando realiza uma atividade, enquanto que o escritor, porque realiza uma função, caracteriza-se como sujeito que "trabalha sua palavra (mesmo se é inspirado) e se absorve funcionalmente nesse trabalho" (BARTHES, 1999, p. 33, grifos do autor).

Aparentemente abatido em pleno voo, em prol dos poderes do texto - nesse percurso breve que vem desde Mallarmé até os teóricos de fins de século XX e início de XXI -, a figura do autor parecia fadada a se transformar em uma forma fantasmática, reduzida a um nome na lápide-livro. No en-

\footnotetext{
1 "Embora o império do Autor seja ainda muito potente (a nova crítica não fez mais do que o consolidar), é claro que certos escritores, desde há muito, vêm tentando abalá-lo" (tradução nossa).
} 
tanto, a contemporaneidade concedeu ao escritor um salvo-conduto, transformando-o em uma das espécies de transbordamento do texto, dos restos do texto, que Josefina Ludmer aponta e que a crítica náo consegue recolher. O autor, assim, é um desses "restos" de que fala Josefina Ludmer, posto que é revelado como potência a ser resgatada pela abordagem polifônica das obras - algo que Roland Barthes já intuíra -, ao se observarem os resíduos da análise funcional, denotados no real concreto tomado como referência primordial ao discurso narrativo, o qual, por sua vez, autentica esse mesmo real (BARTHES, 1972). Como se vê, a cena crítica do autor é espaço amplo de questionamentos e possibilidades que, náo podendo figurar em toda sua dimensão nos limites deste trabalho, requer um recorte. Ao chamarmos à discussão dois escritores do hoje, levamos em conta tal necessidade.

Na narrativa de Bernardo Carvalho, para início de discussão, a questâo do autor é ficcionalizada de forma extremamente ambígua. Por um lado, o autor diz não se identificar completamente com a ideia do escritor tout court; pelo menos, náo da forma com seus pares contemporâneos o fazem, e acrescenta que ter que lidar com sua classe "é um negócio muito difícil", uma "convivência que [me] paralisa" (CARVALHO, 2011, p. 159). Entretanto, instado a falar e a escrever em vários lugares do mundo (seja por meio de projetos, bolsas de residência, convites oficiais, participaçôes em eventos literários etc.), Carvalho revela-se sujeito do mesmo mundo que problematiza em suas obras, seja através da discussão ficcional de seu projeto criador, seja através da discussáo acerca das diferentes formas de solidão da escrita e do escritor, inclusive, arriscadamente assemelhadas à imagem clássica que fazemos do autor:

[...] eu só consigo dar sentido ao que faço se isso estiver fora de um contexto maior. Por isso, me sinto tão bem como estrangeiro. Dentro do contexto, é estranho, parece que as coisas não fazem sentido. $\mathrm{O}$ que eu faço, se estiver contextualizado, nâo tem sentido nenhum. Preciso estar fora (CARVALHO, 2011, p. 160).

Nesse sentido, seu mais recente romance, Simpatia pelo demônio (2016), lido aqui em relação ao conjunto de sua já extensa obra, pode ser reconhecido como uma forma de o autor ampliar o debate acerca da autoria (da própria autoria) e das práticas que a estruturam nos campos literário e intelectual, mormente quando ficcionaliza os meios e as condiçóes pelos quais sua autoimagem construída reverbera dentro de um sistema no qual aquilo que ele, como autor-empírico, diz de si e se encontra intensamente 
dramatizado no "como se" da linguagem literária criada: através dessa linguagem, a explicação de si converte-se em complicação de si.

Exemplo bastante característico da explicação de si que se converte em complicação de si é a própria gênese da produção de Simpatia pelo demônio. Nesse trabalho, Carvalho contou com o auxílio de bolsas de residência do Daad Berliner Künstlerprogramm e da Passa Porta - Casa Internacional de Literatura em Bruxelas. Assim como em algumas obras anteriores, o romance tem participação de agências de fomento e estímulo a escritores. Essa relaçáo é ficcionalizada em suas obras, e, em Simpatia pelo demônio, a personagem principal, Rato, é um funcionário em processo de demissão de uma agência humanitária que se vê rodeado de dilemas morais, como o uso de sua influência para algumas vantagens pessoais e a missáo secreta que contraria as normas da própria agência. Essa posição instável, ambígua, do escritor-intelectual é um dos elementos da inserçâo autoficcional nas obras de Carvalho.

Julián Fuks, por sua vez, também defende uma escrita na qual a experiência será trabalhada pela invenção, pela memória e pela linguagem. Segundo o autor, essa visão pessoal do processo da escrita fez com que ele se aproximasse da autobiografia. No ensaio "A era da pós-ficção: notas sobre a insuficiência da fabulação no romance contemporâneo" (2017, p. 77), Fuks afirma que o retorno das escritas de si, "das narraçôes sem narradores típicos, conduzidas pela voz quase imediata dos autores, dos sujeitos cujos nomes se estampam nas capas dos livros", povoadas por "figuras preexistentes à própria obra”, aponta para a necessidade de o romance reinventar-se como gênero. Muito embora seu premiado $A$ resistência seja comumente considerado uma autoficção, Fuks prefere classificá-lo como "pós-ficção", cujo conceito explica em uma entrevista concedida à revista Época:

\footnotetext{
A definiçẫo de autoficçẫo é centrada na figura do autor, que ficcionaliza suas vivências, aproximando o romance da autobiografia. Mas uma questáo mais ampla é o modo como a literatura tem tocado diretamente diversas realidades e se deixado atravessar por diversos discursos, além do autobiográfico, como os discursos histórico, político e ensaístico. O termo "autoficçáo" não dá conta da literatura atravessada por todos esses processos, pois fala só da ficção atravessada pela biografia. O que me interessa é a ficção que se deixa permear pelo real, se confunde com o real, se funde com o real. A "pós-ficção" é uma ficção transformada, ocupada pelo real .
}

Para a discussão desses temas, importam-nos os questionamentos 
acerca do espaço biográfico (ARFUCH, 2010); das escritas de si e do retorno do autor (KLINGER, 2012;AZEVEDO, 2008; LEJEUNE, 2008; DOUBROVSKY, 1977), questóes que retomam o problema intensamente analisado tanto por Roland Barthes quanto por Michel Foucault; de algumas reflexóes de Jacques Derrida sobre a auctoritas, o narcisismo de origem (o problema do nome) e a literatura como instituiçáo estranha da qual o autor participa em um instável e problemático dentro/fora (DERRIDA, 1992; 1995; 2005), além do trabalho de Umberto Eco (1994), essencial para uma sistematização das relaçôes entre autor-modelo e autor-empírico. Esse pequeno conjunto de autores amplia e redefine questôes da autoria pioneiramente estabelecidas por Roland Barthes e Michel Foucault.

\section{O autor e a escrita de si}

Contamos histórias porque afinal de contas as vidas humanas precisam e merecem ser contadas.

(Paul Ricoeur, Temps et récit)

A função autoral é um construto produzido por forças culturais que atendem a demandas específicas de uma determinada época. Se, no século XVIII, o autor assumiu o estatuto de proprietário de textos originais, circunscritos por uma intencionalidade que, ao longo do século XIX, esteve associada aos métodos de análise do texto literário, por outro, no século XX, com a emergência da perspectiva estruturalista, a concepção do texto como um tecido de citaçôes levou ao banimento do autor (BARTHES, 2004), que cede espaço à primazia da escritura. Para Sérgio Luiz Prado Bellei (2018, p. 164), a proposta de Roland Barthes questionava radicalmente "toda e qualquer origem em função do entendimento do texto enquanto espaço não unificado de dispersão e unificação de significados fora de controle”. Será Michel Foucault, ainda segundo Bellei (2018, p. 166), quem complementará a proposta barthesiana, problematizando a dinâmica "aparecimento e desaparecimento" que ronda o tema. Uma análise mais detida do texto de Foucault nos ajuda a entender mais a fundo o problema.

Em O que é um autor? (2001), Michel Foucault discute a função autoral, demonstrando que ela é um construto produzido por forças culturais que atendem a demandas específicas de uma determinada época. Para Foucault, não basta questionar a intencionalidade da obra, ou mesmo atribuir 
à crítica um papel exegético. Sinalizando o enfraquecimento da figura do autor, que, como vimos, vem desde Mallarmé e chega a Blanchot, Foucault mostra que o processo da escrita resulta no apagamento do autor em sua singularidade existencial, permitindo que o nome ocupe o seu lugar (FOUCAULT, 2001, p. 294). Escrever passa a ser equivalente a desaparecer, com a consequente política do nome, que se desloca da figura de um ente civil para a concepção de autor-modelo como um conjunto de estratégias textuais, isto é, um conjunto de instruçôes, como bem aponta Umberto Eco (1994), com as devidas diferenças interpretativas e visôes críticas em torno desse tema:

[...] meu autor-modelo não é necessariamente uma voz gloriosa, uma estratégia sublime: o autor-modelo atua e se revela até no mais pífio dos romances pornográficos ara nos dizer que as descriçôes apresentadas devem constituir um estímulo para nossa imaginação e para nossas reaçóes físicas (ECO, 1994, p. 23).

Essa dessacralização do autor e da própria obra, agora sem a inscrição de um Pai da escrita, revela apenas o texto, discurso que aponta para diferentes percepçóes do esvaziamento da figura do autor, o que, segundo Jacques Derrida (1995, p. 23, grifos do autor), faz parte do movimento de toda auctoritas, isto é, o retorno ao nome que permite "no mais secreto de teu nome, poder desaparecer em teu nome". Portanto, voltando a Barthes, a problemática do esvaziamento do nome significa uma espécie de deslizamento da produçáo textual para a recepçáo; já para Foucault, esse esvaziamento se dá por meio da substituição da funçáo do autor, que "é característica do modo de existência, de circulação e de funcionamento de alguns discursos na sociedade" (FOUCAULT, 1992, p. 46). Paradoxalmente, será o próprio Barthes quem abrirá novos espaços críticos para a discussão de uma "certa" volta do autor:

O prazer do texto comporta também uma volta amigável do autor. $\mathrm{O}$ autor que volta não é por certo aquele que foi identificado por nossas instituiçôes (história e ensino da literatura, filosofia, discurso da Igreja); nem mesmo o herói de uma biografia ele é. $\mathrm{O}$ autor que vem do seu texto e vai para dentro da nossa vida não tem unidade; é um simples plural de 'encantos', o lugar de alguns pormenores tênues, fonte, entretanto, de vivos lampejos romanescos, um canto descontínuo de amabilidades, em que lemos apesar de tudo a morte com muito mais certeza do que na epopeia de um destino; náo é uma pessoa (civil, moral), é um corpo (BARTHES, 2005, p. 16). 
Em Simpatia pelo demônio, por exemplo, Bernardo Carvalho informa, nos paratextos, sua vinculação com entidades de apoio financeiro a escritores, e essa relação é problematizada no romance. Ao mesmo tempo em que o dado referente à entidade civil do autor se faz presente, a ficcionalização propóe uma interseçấo entre o desejo do leitor de identificar o dado biográfico no ficcional e a compreensão de que, na obra, o que há é um conjunto de estratégias conceituais, no qual o autor é um dado, dentre outros. Daí que as passagens biográficas que, porventura, identificamos no romance serão sempre um aspecto daquilo que Roland Barthes definiu como "canto descontínuo de amabilidades", ou seja: não sendo o autor uma pessoa, um ente civil ou moral, ele, no entanto, faz parte do corpo conceitual que alimenta o texto. Seu lugar é sempre dentro-fora, instável.

$\mathrm{Na}$ trilha aberta por Roland Barthes, Diana Klinger (2012) defende que o retorno do autor se dá por meio da busca de um efeito de real que, no caso do que se convencionou chamar de autoficção, não visa à verossimilhança interna da ficção, mas a algo que está além dela. A autora vê uma transgressão do pacto ficcional nas modalidades de romance que "problematizam a ideia de referência e assim incitam a abandonar os rígidos binarismos entre "fato" e "ficção" (KLINGER, 2012, p. 11), o que anteriormente Jacques Derrida (1995, p. 41) assim pensara: "entre o autor e o analista, seja qual for a distância, sejam quais forem as diferenças, a fronteira parece, portanto, incerta. Sempre permeável”.

Esse conjunto de elementos que transpassam os textos e que dele transbordam tem que contar com a vinda participativa de um leitor crítico, já objetivado no texto, uma vez que os leitores críticos como um todo não procedem a análises equivalentes. Assim como o autor se manifesta nos restos do texto, esse leitor crítico pressuposto também se expóe à violência da diferença: "Por certo, o crítico e o não-crítico não são idênticos, mas permanecem, no fundo, a mesma coisa. Em todo caso, participam disso" (DERRIDA, 1995, p. 8). Da mesma forma que permanece obscura a figura do autor, no sentido de tentar objetivá-lo, o leitor pressuposto é uma marca do discurso, igualmente desconhecido. E, no entanto, ambos, autor e leitor, estâo hoje guardados pelos signos do retorno. Historiar alguns princípios conceituais do hoje acerca desses problemas, no que diz respeito à autoficção, nos soa produtivo para o que se analisa em relação aos dois romancistas escolhidos.

Luciane de Azevedo (2008, p. 31) define autoficção como "uma estratégia da literatura contemporânea capaz de eludir a própria incidência do 
autobiográfico na ficção e tornar híbridas as fronteiras entre o real e o ficcional, colocando no centro das discussôes novamente a possibilidade do retorno do autor". O termo autoficção, sempre é bom recordar, foi cunhado por Serge Doubrovsky, em 1977, que o inseriu na quarta capa do seu romance Fils, em uma resposta concreta à indagaçáo feita por Philippe Lejeune sobre a possibilidade de existência de um romance em que o autor e o personagem compartilhassem o mesmo nome.

Philippe Lejeune publicara, em 1975, a obra O pacto biográfico, na qual afirmava que há elementos-chave para a distinção da autobiografia em relação a outros gêneros, como a biografia e o romance: a) o texto na forma de prosa narrativa; b) a história pessoal de um narrador autodiegético e, finalmente, c) uma relaçấo de identidade entre autor, narrador e personagem, firmando uma espécie de contrato social, no qual o autor atesta a sua existência e a veracidade de seus escritos (LEJEUNE, 2008, p. 23). Para tanto, o nome da personagem principal deveria ser, necessariamente, idêntico ao nome do autor que está estampado na capa do livro. Para Lejeune, essa identidade onomástica não ocorreria no romance, tese de certa forma posta por terra com o lançamento de Fils, de Doubrovsky.

Na visão de Doubrovsky, a autoficção exige uma correspondência do nome entre autor, narrador e herói romanesco, similar à autobiografia. Instaurando o presente como o tempo próprio da lembrança, ele insere a escrita de si entre os gêneros referencial e ficcional; porém, adverte para o fato de que a autoficção deve ser lida como romance, pois não reproduz a vida do autor, recria-a por meio de palavras. Há assim uma ruptura da autoficção com o princípio da veracidade, ou seja, com o pacto autobiográfico; no entanto, isso também não implica uma total adesão ao princípio de invenção ou ao do pacto romanesco, mas, situa-se a meio termo entre ambos, concretiza um pacto oximoro, que concilia os dois outros.

No caso específico do romance A resistência, de Julián Fuks, é possível observar um desvio do modelo sugerido por Doubrovsky, pois não há correspondência entre os nomes do narrador e do autor. Fuks constrói o narrador, nomeado Sebastián, como uma representação discursiva de si. Assim, o nome do autor, impresso na capa, não remete diretamente à personagem, cuja identificação com o autor se dá por outros meios, mormente os midiáticos.

Da mesma forma, em boa parte da obra de Bernardo Carvalho, vemos uma relaçáo possível entre sua poética e aquilo que Fuks chamou de "ficção que se deixa permear pelo real", com ele se confundindo e fundindo, em 
espécie de ficção transformada. Esse processo diz muito, porém não tudo, sobre o projeto criador que permeia os romances mais recentes de Carvalho, especialmente, a partir de Nove noites (2002). Nessa obra, por exemplo, sabemos que um jornalista e escritor de romances, ao ler, por acaso, um artigo de jornal, no dia 12 de maio de 2001, sobre a misteriosa morte do antropólogo americano Buell Quain, que supostamente se suicidara entre os índios krahô, em 1939, toma para si a tarefa de recuperar os fatos históricos, na tentativa de dar um sentido ao evento traumático do etnólogo suicida e, veremos no decorrer da leitura, de preencher algumas lacunas de sua própria vida e de seu passado. Assim, o jornalista buscará, inicialmente, uma aproximação com a antropóloga autora do artigo, a fim de coletar as primeiras informaçóes sobre o caso, sem que o leitor, inicialmente, ou, mesmo, ao longo da narrativa, saiba, exatamente, quais motivos levam o jornalista-narrador a pesquisar aquele momento inusitado da antropologia brasileira.

Nasce, daí, uma narrativa que se deixa permear pelos fatos históricos e pelo real, confundindo, de passagem, autor e narrador, por exemplo: Bernardo Carvalho, assim como seu personagem-narrador, escreve para a Folha de São Paulo; nos agradecimentos, ao final de Nove noites, o suposto Carvalho autor-empírico menciona, nos agradecimentos, a antropóloga Mariza Corrêa, como dissemos, autora do artigo que detona no jornalista e narrador uma verdadeira busca obsessiva pela verdade dos fatos. Corrêa é personagem incidental da trama, como o leitor-crítico logo perceberá. Além dela, outras marcas extratextuais, ou epitextuais, como uma foto na terceira capa, em que vemos o autor aos seis anos, no Xingu, ao lado de um índio, para ficarmos em mais um exemplo. De fato, essa mescla de real e ficcional, de pesquisa histórica e invenção, faz de um conjunto de estratégias textuais - que, na obra de Carvalho, assumem uma espécie de norte para o leitor -, espécie de guia para passeios inferenciais que, inclusive, nos auxiliam a compreender sua ficção posterior, como é o caso de Simpatia pelo demônio (2016). Dando um salto, portanto, para a leitura crítica desse mais recente romance de Carvalho, nossa discussáo dependerá de algumas modulaçóes, dentre elas, a questão dos paratextos, que nos auxiliam a pensar os movimentos do autor, no caso específico do que estamos a investigar aqui.

Segundo Gérard Genette (1997), os paratextos são integrados pelos peritexto - formatos, capas, título, título dos capítulos, tipos de letras, imagens etc. - e epitexto, que seriam as relaçóes inscritas no exterior da obra, como, por exemplo, o editor, as críticas, mediaçôes, autocomentários etc. (em se tratando do epitexto público); e as correspondências, confidências orais, diários, pré-textos, que fazem parte do epitexto privado. Tratando des- 
sas relaçóes como um todo, abrigando-as sob o guarda-chuva do paratexto, chama-nos a atenção, de início, o recorte de Claudia Espínola de Carvalho sobre a tela São Cristóvão carregando o Menino Jesus, de Hieronymus Bosch (1490), cujos detalhes nos revelam alguns elementos intrínsecos à discussão crítica no romance carvaliano. Por meio de uma breve pesquisa, saberemos que Bosch era um conservador que, no entanto, foi considerado um artista subversivo, pintor de monstruosidades e quimeras, cujo trabalho é definido como estranho e fantasioso. Suas obras ilustram conceitos morais e religiosos, alguns, de forma polêmica. Como o leitor atento pode ver, a imagem de Carvalho como autor aqui aparece, ainda que velada, ou melhor, de forma muito sutil, inscrita, no texto, por meio de elementos aparentemente dispostos fora dele, mas manifestos no diálogo com outra espécie de arte - a visual - que, sendo uma das formas do resto do texto, possibilita uma volta à cena da figura autoral e, com ela, também o desnudamento de algumas inferências essenciais propiciadas nessa vinda: é notória a relação de Bernardo Carvalho com o mundo das artes plásticas e do teatro, bem como com o exercício da crítica nas searas da pintura, do cinema etc.

Se observarmos atentamente os elementos paratextuais mais explícitos da obra, teremos ciência, por meio do epitexto, de que o autor-empírico obteve financiamento de bolsas de residência do Daad Berliner Künstlerprogramm e da Passa Porta - Casa Internacional de Literatura em Bruxelas, o que é também uma marca da biografia do autor e de sua prosa, a qual, pelo processo de seleção e combinação daquilo que transfigura o real em texto, desnuda os atos de fingir específicos de sua poética (ISER, 1983).

No plano da enunciação, Simpatia pelo demônio divide-se entre Berlim, Nova York e um país não identificado, assolado pela guerra e pelo terrorismo, para onde viaja a personagem central, em uma missáo secreta de resgate de um prisioneiro, após ser demitido de uma agência humanitária para a qual trabalhava, após 10 anos comandando a Seção de Zonas de Conflito. Sabemos que o Rato, personagem assim apelidado, tem 55 anos, idade do autor à época da escrita da obra, e que ele é um cidadáo do mundo, realizando trabalhos em diversos pontos do globo, principalmente em zonas de exclusão, como acampamentos humanitários, territórios em conflitos, geografias de guerra e êxodo etc. A homologia entre o personagem como um sujeito do mundo e a atitude de Carvalho como um escritor migrante, que precisa isolar-se para escrever, entretanto, sempre se colocando em movimento, são pistas importantes para se discutir a função autoral. Não queremos aqui propor uma leitura forçada de "coincidências", mas mostrar que as estratégias textuais de Carvalho apontam para a singularidade de seu 
projeto, que dialoga e, ao mesmo tempo, se afasta de outras obras e de outros autores, especificamente se pensarmos no batismo dos nomes das personagens que, no caso de Carvalho, não sendo identificadas pela homologia entre o sujeito representado e o autor-empírico, remetem ao autor-empírico através de caminhos difusos, enviesados, estabelecidos nas estratégias ficcionais criadas. $\mathrm{Na}$ verdade, queremos dizer que a ideia de uma relação de imbricaçáo entre os elementos do peritexto e do epitexto faz, da escrita de Carvalho, um híbrido de vários discursos, identificados, no caso de Simpatia pelo demônio, nas inferências acerca das Artes Plásticas, da Psicanálise, Ciência Política, Geografia, Cartografia, Etnologia etc.

O autor-empírico Bernardo Carvalho também se apresenta como uma entidade - ficcional ou não - que, no plano dos epitextos, trava diálogos produtivos com o leitor-crítico, como quando esclarece o título da obra - que remete à conhecida canção homônima dos Rolling Stones, "Simpathy for the Devil" - orientando a leitura na direçáo de que o sentido dado por ele é diverso do atribuído à canção. Carvalho afirma que sua obra não deve ser lida como "consideração", "solidariedade", traduçóes do falso cognato simpathy para o português, mas na acepção de "simpatia", conforme é dado em nosso contexto de língua.

Ainda no plano do enunciado, veremos que a atração pela monstruosidade, pelo abjeto, pelo sombrio, pelo mórbido perpassa todo o texto, nas duas vertentes que ele estabelece, ou seja, de um lado, a história do Rato como agente secreto enviado a uma missão suicida; de outro, a história de sua relaçáo pessoal com o Chihuahua, por quem se apaixona e com quem desenvolve uma relação de poder, masoquismo e perversóes. Decorre daí que os elementos dispostos pelo autor nas epígrafes podem ser índices de suma importância para se entender a questão da função autoral. Podemos percebê-la (1) na epígrafe de Malcolm Lowry, retirada de À sombra do vulcáo ("Sempre que precisar de uma sombra, pode contar com a minha"); (2) em dois versos retirados da canção "Half a person", do The Smiths ("Call me morbid, call me pale / I've spent sixy ears on your trail”); e (3) sem nos alongarmos, na passagem de História do olho, de Georges Bataille: "Como se eu tivesse querido escapar ao abraço de um monstro e o monstro fosse a violência dos meus movimentos" (Cf. CARVALHO, p. 8-10).

Esses poucos exemplos são encontrados em abundância na obra de Carvalho. Na própria articulação entre a função autoral e as marcas deixadas pelo escritor, revelam-se processos que diferem das poéticas dos demais escritores. Em Carvalho, a política do nome como uma das "marcas auto- 
biográficas", como chama Diana Klinger (2012, p. 13), pode ser "o ponto de confluência entre uma tendência literária e uma epistemológica”. Como Klinger não chega, em seu excelente trabalho - Escritas de si, escritas do outro, de 2007, e relançado em 2012 -, ao momento atual da obra de Carvalho, acrescentamos que, à virada etnográfica, se estabelece, em Simpatia pelo demônio, uma exacerbação do caráter híbrido e ensaístico de sua ficção, dada pela relação plurissignificativa entre os paratextos e a figura do autor, que os aloca de forma a nos comunicar que seu lugar como escritor é da ordem do paratópico (MAINGUENEAU, 2000) por excelência, isto é: a figura do autor é instável, está dentro/fora do campo literário, mas frisemos que essa instabilidade se faz presente na literatura de hoje como dado ficcionalizado com muita propriedade por certos escritores, dentre os quais inserimos Carvalho.

Autores como Bernardo Carvalho pensam a parole e a narração dentro do processo etnobiográfico (GONÇALVES; MARQUES; CARDOSO, 2012), transitando entre uma forma de experiência individual, de cunho autobiográfico, e outra, mais coletiva. Fala e narração, ao invés de serem tomadas como um tipo de discursividade com vistas a certa neutralidade, denotam, na verdade, uma virada etnográfica em que ambas são percebidas como pura agência, na medida em que o retorno do autor não ocorre sem uma crítica contundente ao processo de representação. Isso implica uma transfronteirização do conhecimento que toma a cultura como problemática, ao diluir os limites precisos entre real e ficcional (KLINGER, 2012). Por estarem, ao mesmo tempo, nesse dentro/fora, os escritores à moda de Carvalho atuam no campo literário à maneira dos etnógrafos. No entanto, em sua autoetnografia, o indivíduo que fala náo se elimina daquilo que fala, ao contrário, ele marca uma diferença crítica entre o que é enunciado e a enunciação.

Desse modo, se, por um lado, conseguimos identificar, na experiência biográfica, uma série de elementos que dizem respeito ao autor de Simpatia pelo demônio - a ambientaçáo da trama em Berlim, por conta do financiamento do DAAD; os deslocamentos da personagem Rato por regióes as mais diversas do mundo, também uma característica do autor; as discussóes sobre artes plásticas, teatro, política, pelas quais identificamos o eu-civil Bernardo Carvalho etc. -, o leitor deverá, por outro viés, compreender a intensa problematizaçáo desse retorno do autor, pois o real ali representado recusa aproximação com o retrato. Fato e ficção são problematizados, desta feita, por uma terceira pessoa narrativa que sugere objetividade, mas nos entrega um mundo de fronteiras borradas. A própria matéria discursiva do romance 
será guiada por esse princípio: saberemos da vida da personagem Rato após a explosão de uma bomba em seu hotel, nos poucos minutos em que, aturdido, ele repassa sua vida recente. Decorre daí o caráter difuso do relato, o que nos faz questionar a suposta veracidade dos fatos narrados.

Pensando nesses elementos que rondam a figura autoral e as obras, em seguida, iremos discutir alguns problemas da autoria, pensando em outra forma de escrita narrativa e de projeto poético, no caso, a obra de Julián Fuks, mais especificamente, no romance A resistência (2015). Com esses dois exemplos, de Bernardo Carvalho e Julián Fuks, esperamos contribuir para uma intervençâo produtiva, ainda que parcial, nos problemas que envolvem a ideia de autor e autoria, hoje.

Nas muitas entrevistas concedidas na época do lançamento de A resistência e, posteriormente, ao ganhar o prêmio Jabuti, Fuks admitiu que a motivação para a escrita do romance deveu-se a uma sugestão dada por seu irmão, Emi, que, em meio a uma crise familiar, lhe dissera que escrevesse sobre a sua adoçáo, realizada quando os pais do autor ainda viviam na Argentina e supunham não poder ter filhos naturais:

\begin{abstract}
[A resistência] é uma narrativa de autoficção, construída a partir de uma série de vivências familiares. Tem como ponto de partida a adoção do meu irmão, antes que eu nascesse, e a militância dos meus pais durante a ditadura militar argentina, a perseguição de que foram vítimas, o exílio no Brasil. Para tratar de assuntos táo íntimos, táo pessoais, me pareceu importante abordar a questáo da forma mais direta e sincera possível, e a voz em primeira pessoa, em tom que evoca o confessional, foi a única possível para isso. Mas é claro que o livro nâo retrata de maneira literal a experiência vivida: há ficção na medida em que há construção estética, a constante escolha da forma mais expressiva de narrar essas histórias .
\end{abstract}

A construção estética é exposta na narrativa na medida em que, em diversas passagens, o próprio narrador se coloca em dúvida sobre a matéria narrada, discutindo o estatuto da sua ficção, bem como os limites da representação:

Isto não é uma história. Isto é história. Isto é história e, no entanto, tudo que eu tenho ao meu dispor é a memória, noçóes fugazes de dias tão remotos, impressóes anteriores à consciência e à linguagem, resquícios indigentes que eu insisto em malversar em palavras. Não se trata aqui de uma preocupação abstrata, embora de abstraçóes eu tanto me valha: procurei meu irmão no pouco que escrevi até o momento e náo o encontrei em parte alguma [...] 
Não se depreenda desta observação desnecessária, ao menos por enquanto, a minha ingenuidade: sei bem que nenhum livro jamais poderá contemplar ser humano nenhum, jamais constituirá em papel e tinta sua existência feita de sangue e de carne [...] Encontro um álbum de fotos cruzado na estante, largado no ângulo exato que o faça casual. Tenho que virar algumas páginas para que enfim me assalte o rosto do meu irmão [...] Por que não consigo lhe passar a palavra, lhe imputar nesta ficção qualquer mínima frase? Estarei com este livro tratando de lhe roubar a vida, de lhe roubar a imagem, e de lhe roubar também, furtos menores, o silêncio e a voz? Náo consigo decidir se isto é uma história (FUKS, 2015, p. 23).

O romance inteiro é carregado desse tipo de ambiguidade, e o narrador não se furta a admitir que preenche deliberadamente as lacunas da história de seus familiares. Em um dado momento, ao se deparar com uma fotografia dos pais ainda jovens, se reporta a ambos como "seres históricos", afirmando ainda que o drama de sua narrativa se desloca entre uma mentira e outra (FUKS, 2015, p.36), estabelecendo, assim, uma equivalência entre mentir e fabular.

A instabilidade entre o referencial e o ficcional se projeta no romance por meio da dúvida do narrador quanto aos fatos narrados:

Quase tudo que me dizem, retiram [...] sei e não sei que meu pai pertenceu a um movimento, sei e não sei que fez treinamento em Cuba, sei e não sei que jamais desferiu um tiro com alvo certo, que se limitou a atender os feridos nas batalhas de rua, a procurar novos quadros, a pregar o marxismo nas favelas. Ele sabe e não sabe que escrevo este livro, que este livro é sobre meu irmão, mas também sobre eles. Quando sabem diz que vai mandar o documento da Operaçáo Condor em que consta o seu nome. Eu lhe peço que me mande, mas náo conto que quero inseri-lo no livro, que pretendo absurdamente atestar minha invenção com um documento [...] ele nunca me manda o arquivo (FUKS, 2015, p. 40).

A falta do documento que deveria endossar a ficção está inserida no jogo da ambiguidade referencial, pois o narrador sutilmente revela que o texto é ardiloso, "é e não é" autobiografia. Essa capacidade de narrar desviando-se sinuosamente do referente é evidenciada quando o narrador, finalmente, entrega aos pais o romance já pronto, para que o leiam, e eles compartilham as dúvidas do narrador sobre a história narrada:

$\mathrm{Na}$ noite passada meus pais leram o livro que lhes enviei, enganaram a insônia com estas páginas, por algum tempo estiveram depurando o que po- 
deria comentar, como lidariam com esta situaçáo um tanto exótica. É claro que não podemos fazer observaçôes meramente literárias, ambos ressalvam como se quisessem se desculpar, durante toda a leitura sentiram uma insólita duplicidade, sentiram-se partidos entre leitores e personagens, oscilaram ao infinito entre história e história. É estranho, minha mãe diz, você diz mãe e eu vejo meu rosto, você diz que eu digo e eu ouço minha voz, mas logo o rosto se transforma e a voz se distorce, logo não me identifico mais. Não sei se essa mulher sou eu, me sinto e não me sinto representada, não sei se esses pais somos nós (FUKS, 2015, p. 137-138).

No romance, o que move o narrador é a busca da origem do irmão adotado, sobre a qual ele forja uma ficçáo, imaginando-o uma das crianças que foram sequestradas durante a ditadura militar na Argentina, para onde vai, na intenção de conseguir dados concretos. Sebastián vê-se, entretanto, como um narrador inadequado à história que gostaria de contar, mergulhando, ao invés disso, na história de seus pais:

\begin{abstract}
Não sei bem o que escrevo. Vacilo entre um apego incompreensível à realidade - ou aos esparsos despojos de mundo que costumamos chamar de realidade - e uma inexorável disposiçấo fabular, um truque alternativo, a vontade de forjar sentidos que a vida se recusa a dar. Nem com esse duplo artifício alcanço o que pensava desejar. Queria falar do meu irmão, do irmão que emergisse das palavras mesmo que não fosse o irmão real, e, no entanto, resisto a essa proposta a cada página, fujo enquanto posso para a história dos meus pais (FUKS, 2015, p. 95).
\end{abstract}

Em sua deambulação por Buenos Aires, Sebastián concede ao leitor mais um elemento identificador da autoficção, pois menciona um livro que escrevera sobre a experiência de caminhar pelas ruas de Buenos Aires. Em Procura do romance, romance publicado por Fuks em 2012, o narrador, igualmente denominado Sebastián, também faz o mesmo percurso em busca lembranças que possibilitem a escrita de um romance.

Essa breve exposição de alguns dos artifícios usados por Fuks ao escrever o romance como uma autoficçáo visa a demonstrar que o conceito carece ainda de uma investigação mais aprofundada, tendo em vista que as práticas narrativas autoficcionais têm apresentado diferentes perfis e desvios da concepção original de Doubrovsky. O próprio Fuks sugere que esta é a era da pós-ficção, de uma tentativa do romance de "fechar a ferida que permanecia aberta desde a radical implosão do gênero" (FUKS, 2017, p. 82) por autores como Woolf e Joyce. Para o autor, à medida que o romance dialoga com 
outros gêneros textuais e com outros campos do saber, como a historiografia, por exemplo, o elemento ficcional é transgredido. Essa característica do romance contemporâneo o situaria na esfera de uma pós-ficção, ainda que na presença do pacto oximoro.

Seja como autoficção ou como pós-ficção, como defende o autor, A resistência apresenta dúvida tanto sobre a sua comprovação quanto com relação à sua verossimilhança (KLINGER, 2012), considerando-se que os operadores de identificação são externos ao romance e estão no âmbito performático da autoria. O autor que fala de sua motivaçáo para a escrita do romance e estabelece o elo entre ele e sua biografia é também um personagem do espaço público midiático; é e não é o autor.

\section{Conclusóes}

Como vimos, obras como as de Diana Klinger (2012) e Leonor Arfuch (2010), dentre outras, vêm reconfigurando, com êxito, as pesquisas sobre a autoria no âmbito da crítica, mas a velocidade das mudanças e os rumos inesperados que a literatura de hoje toma requerem dos pesquisadores uma atenção redobrada para essa "espécie de ubiquidade entre vida e ficçáo" (ARFUCH, 2010, p. 211), situada "nos territórios fronteiriços entre a ficção e a náo-ficção” (KLINGER, 2012, p. 138). Neste trabalho, destacamos as poéticas de dois escritores brasileiros contemporâneos cujas obras investem na discussão do autor e da autoria como tema central das narrativas híbridas que nos entregam.

Os artifícios de Fuks, conforme nossa leitura de A resistência, provocam o campo da autoficção ao ampliar as possibilidades de reflexão, apontando os limites dessa vertente inaugurada, segundo muitos, pelo romancista Serge Doubrovsky, em Fils: roman. Em Bernardo Carvalho, procuramos discutir os elementos que o colocam na condiçáo de sujeito paratópico, em constante negociaçáo com o campo literário, explorando os meandros desse dentro/fora em que o escritor avulta como uma espécie de resto do texto que confere densa significação à complexidade das relaçôes entre autoria, texto e vida, ficcionalizadas em seus romances. Esses campos, ora em sintonia ora em tensão, traduzem a dinâmica da literatura, compreendida por Jacques Derrida (1992, p. 37-38) como uma instituição com suas convenções e regras que, em princípio, tem o poder de dizer tudo, o que implica uma licença ao escritor para que, blindado por esse poder e livre de toda a censura, seja ela religiosa ou política, se comporte "irresponsavelmente", o que para 
Derrida é a mais alta forma de responsabilidade.

Essa responsabilidade se manifesta como uma das possibilidades de resposta à questão "o que é um autor?", seja por meio da crítica, seja através das estratégias do texto ficcional que, como vimos com Carvalho e Fuks, ajudam a reescrever, obra a obra, a história de uma figura ameaçada de extinção em passado recente, mas que retoma, com vigor, seu lugar no campo intelectual contemporâneo: o autor, o nome do autor, a entidade autoral, o recalcado que retorna e reclama seus direitos.

\section{Referências}

ARFUCH, Leonor. O espaço biográfico: dilemas da subjetividade contemporânea. Trad. Paloma Vidal. Rio de Janeiro: EdUERJ, 2010.

AZEVEDO, Luciane A de. Autoria e performance. Revista Brasileira de Literatura Comparada, Associação Brasileira de Literatura Comparada, n. 12, p. 31-49, 2008. Disponível em: <http://revista.abralic.org.br/index. $\mathrm{php} /$ revista/article/download/179/182>. Acesso em: 10 set.2017.

BARTHES, Roland. O efeito de real. In: Literatura e semiologia: pesquisas semiológicas. Tradução Célia Neves Dourado. Petrópolis, RJ: Vozes, 1972. p. 35-44. (Coleção Novas Perspectivas em Comunicação, 3). Seuil, 1984.

Le bruisement de la langue: essais critique IV. Paris: Éditions du Escritores e escreventes. In: Crítica e verdade. Tradução Leyla Perrone-Moisés. 3. ed. São Paulo: Perspectiva, 1999. p. 31-39.

O rumor da língua. Trad. Mário Laranjeira. São Paulo: Martins Fontes, 2004.

BELLEI, Sérgio Luiz Prado. A morte do autor: um retorno à cena do crime. Criaçáo \& Crítica12, São Paulo, Universidade de São Paulo, n. 12, p. 161 - 
171, jun. 2014. Disponível em: <https://www.revistas.usp.br/criacaoecritica/issue/view/5451/showToc>. Acesso em: 20 mar. 2018.

. O instante de minha morte; L' instant de ma mort. Trad. Fernanda Bernardo. Porto: Campo das Letras, 2003; Paris: Éditions Gallimard, 2002. (Edição bilíngue).

. O livro por vir. Trad. Leyla Perrone-Moisés. São Paulo: Martins Fontes, 2005.

. Sade, Fourier, Loyola. Trad. Mário Laranjeira. São Paulo: Martins Fontes, 2005.

CARVALHO, Bernardo. Nove noites. São Paulo: Companhia das Letras, 2002.

. Uma experiência fabricada. Entrevista. Lugar: Revista da Escola

Letra Freudiana, Rio de Janeiro, 7Letras, ano XXX, n. 42, p. 133-160, 2011, v. : il.

. Simpatia pelo demônio. São Paulo: Companhia das Letras, 2016.

CORRÊA, Mariza. Paixão etnológica. Folha de Sáo Paulo, São Paulo, 12 de maio de 2001. Disponível em: <http://wwwl.folha.uol.com.br/fsp/resenha/rs1205200103.htm>. Acesso em: 28 mar. 2017.

DERRIDA, Jacques. This strangeinstitutioncalled literature. An interview with Jacques Derrida. In: . Acts of literature. Edited by Derek Attridge. New York: Routledge, 1992. p. 33-75.

Paixóes. Trad. Lóris Z. Machado. Campinas, SP: Papirus, 1995.

DOUBROVSKY, Serge. Fils: roman. Paris: Éditions Galilée, 1977.

ECO, Umberto. Seis passeios pelo bosque da ficçáo. Trad. Hildegard 
Feist. São Paulo: Companhia das Letras, 1994.

FOUCAULT, Michel. O que é um autor? In: . Estética: literatura e pintura, música e cinema. Tradução Inês Autran Dourado Barbosa. Rio de Janeiro: Forense Universitária, 2001. p. 264-298.

FUKS, Julián. A era da pós-ficção: notas sobre a insuficiência da fabulação no romance contemporâneo. In: DUNKER, Christian [et al.]. Ética e pós-verdade. Porto Alegre; São Paulo: Dublinense, 2017. p. 75-93.

FUKS, Julián. A resistência. São Paulo: Companhia das Letras, 2015.

GONÇALVES, Marco Antonio; MARQUES, Roberto; CARDOSO, Vânia Z. (Orgs.). Etnobiografia: subjetivação e etnografia. Rio de Janeiro: 7Letras, 2012.

GONÇALVES, Marco Antonio. Etnobiografia: biografia e Etnobiografia ou como se encontram pessoas e personagens. In: GONÇALVES, Marco Antonio; MARQUES, Roberto; CARDOSO, Vânia Z. (Orgs.). Etnobiografia: subjetivação e etnografia. Rio de Janeiro: 7Letras, 2012. p. 19-42.

ISER, Wolfgang. Os atos de fingir, ou o que é fictício no texto ficcional. In: LIMA, Luiz Costa (Org.). Teoria da literatura em suas fontes. v. 2. Rio de Janeiro: Francisco Alves, 1983. p. 384-416.

KLINGER, Diana. Escritas de si, escritas do outro: o retorno do autor e a virada etnográfica. 2. ed. Rio de Janeiro: 7Letras, 2012.

LEJEUNE, Philippe. O pacto autobiográfico: De Rousseau à Internet. Organização de Jovita Maria G. Noronha. Trad. Jovita Maria G. Noronha; Maria Inês Coimbra Guedes. Belo Horizonte: Editora UFMG, 2008.

LUDMER, Josefina. O resto do texto. In: Intervençốes críticas. 
Trad. Ariadne Costa; Renato Rezende. Rio de Janeiro: Azougue; Circuito, 2014. p. 21-24.

MAINGUENEAU, Dominique. O contexto da obra literária: enunciação, escritor, socie-dade. Trad. Marina Appenzeller. 2. ed. São Paulo: Martins Fontes, 2001.

RICOEUR, P. Tempo e narrativa. Tomo I. São Paulo: Martins Fontes, 2010. 